\title{
Time Variations of the Vertical Component in Some of Japanese GEONET GNSS Sites
}

\author{
S. Shimada, M. Aichi, T. Harada, and T. Tokunaga
}

\begin{abstract}
We analyze the vertical component of GEONET GNSS measurements in Central Japan and clarify in some of the sites the origin of large annual time variations, as well as the secular variations. Many of these vertical movements may be attributable to the use of groundwater for agriculture, for snow melting, industrial, and hospital usages, etc. and the pumping up of the groundwater mining for refining natural gas and iodine at the production area of natural gas dissolved in water. For this reason, highly accurate monitoring of vertical variations by GNSS observations can provide new observation methods for understanding of not only geodynamics but also hydrology through monitoring groundwater fluctuation, and natural gas and oil resource development through monitoring ground movements caused by mining.
\end{abstract}

\section{Keywords}

GEONET · GNSS · Groundwater · Vertical component

\section{$1 \quad$ Introduction}

In GNSS observation, ground deformation due to human activity is observed in addition to crustal deformation due to geodynamics such as plate motion, seismic and volcanic activities. In particular, the vertical component is sensitive to the variations due to human activities such as groundwater usage and natural resource mining in the shallow area near the observation site. Regarding these human activities, there are many research subjects in hydrology and resource engineering, and GNSS measurements can contribute to these research fields.

In fact, recently even the vertical component of GNSS permanent station position time series has reached millimeter accuracy, and significant ground movements caused by groundwater usage have been detected at some GEONET

S. Shimada $(\bowtie) \cdot$ M. Aichi $\cdot$ T. Tokunaga Graduate School of Frontier Sciences, the University of Tokyo, Kashiwa-Shi, Chiba Prefecture, Japan e-mail: shimada@envsys.k.u-tokyo.ac.jp

T. Harada

JX Nippon Oil \& Gas Exploration, Tokyo, Japan observation sites, the CORS sites in Japan (Miyazaki et al. 1998). Surface deformation due to atmospheric, oceanic and hydrological seasonal loading may affect the GNSS solutions on vertical component. For example, continental hydrology loading deformations can be computed using the Global Land Data Assimilation System GLDAS (2020) model (Rodell et al. 2004). The EOST Loading Service (2015) provides the map of the annual vertical deformation where it can be noticed that hydrological loading effect is small over Japan. Recent major sophisticated GNSS analyzing software packages, such as GAMIT/GLOBK software (Herring et al. 2018), have already involved enough accurate models of seasonal atmospheric and ocean tidal loading which has the largest power among those loadings over Japan (Dong et al. 2002). Among those models, for instance in the case of GAMIT/GLOBK software, NAO99b by Matsumoto et al. (2000) includes Sa, Ssa, Mm, and Mf long period tides and is accurate especially near and around Japanese islands because tide gauge observations in the region are assimilated in the model. We use GOTIC2 program (Matsumoto et al. 2001) to calculate amplitude and phase of solid earth and ocean load tides for all Japanese and most of global IGS sites. 
Heki (2001), Heki (2004) and Munekane (2010) study on various factors that influence the annual variations of GEONET sites. Munekane (2010) quantitively evaluates subsidence caused by groundwater pumping for agricultural usage in Tsukuba GSI Campus, but carefully checking of those papers, none of them evaluates quantitively subsidence caused by snow loading from the viewpoint of hydrology. Moreover, Geospatial Information Authority of Japan (GSI) in Heki (2001) adopted a specific processing that lead to erroneous vertical annual displacements. Although Tsukuba GSI Campus is showing significant annual variations by the nearby groundwater pumping for agricultural usage (Tobita et al. 2004; Munekane et al. 2004, 2010), the coordinates of Tsukuba IGS/GEONET site were fixed to ITRF96 (Boucher et al. 1998) and the coordinate solution of each GEONET network site then derived by applying the backbone/cluster approach (Miyazaki et al. 1997; Hatanaka et al. 2003; Nakagawa et al. 2009). Thus, Heki (2001) shows time series of vertical coordinate solutions at Naruko and Shizukuishi GEONET sites, but most of the annual variations at those sites are fake motions brought by the erroneous analysis strategy of F1 solution. However the more accurate horizontal coordinates of GEONET sites bring realistic estimations of snow depth distribution in Japanese Island.

In this paper, we report secular and annual variations of the vertical components due to the pumping of groundwater for agricultural and snow melting usages and the extraction of water-soluble natural gas, observed at the GEONET sites in central Japan. As mentioned above, the annual vertical deformations predicted by classical hydrological model over Japan are equal or less than $3 \mathrm{~mm}$ (EOST Loading Service 2015), far smaller compared with those amplitude due to the pumping of groundwater for agricultural, snow melting, and water-soluble natural gas we report. The displacement due to atmospheric loading is evaluated in the GAMIT/GLOBK program applying the ECMWF global model (Tregoning and Herring 2006).

\section{$2 \quad$ Data}

We analyze more than 100 GEONET sites in Kanto area and more than 50 sites in Niigata region both in Central Japan, using GAMIT/GLOBK program with ITRF2014 reference frame, using IGS final and repro2 precise ephemerides with around 30 IGS fiducial sites in and around East Asia. The reference sites are the following: ARTU, BJFS, CHAN, DAEJ(TEAJ), GUAM, GUUG, HYDE, IRTJ(IRKT), KIT3, KOKB, KWJ1, LHAZ(LHAS), MAG0, MCIL, MKEA, NRIL, NVSK, PETP, PIMO, POL2, SHAO, SUWN, TIXI, TNML, TSKB, ULAB, URUM, USUD, WHIT, WUHN, YAKT, YELL. The reference sites are chosen from the sites whose coordinates and velocities are accurately determined in ITRF2014 reference frame (Altamimi et al. 2016). Some of them especially Japanese domestic sites are excluded after 2011 Eastern Japan Great Earthquake, because of large postseismic movements. The area where the reference points locate is almost the same as in Fig. 80.2 of the former paper (Shimada 2012).

We estimate simultaneously site coordinates, independent ambiguities, hourly ZTD, and four-hourly atmospheric gradient at every sites Japanese and IGS sites mentioned above for the daily GAMIT analysis. Then we estimate every site coordinates and daily ZTD in the daily GLOBK analysis, applying a 30day-window Kalman filtering to remove short period noise from daily coordinate solutions. The uncertainties of vertical component are usually significantly large compared with horizontal component, but after applying a 30day-window Kalman filtering the one sigma uncertainties of vertical component are less than $3 \mathrm{~mm}$ for all Japanese sites.

Because groundwater usages induce mainly vertical ground movements, we evaluate the time series of vertical components in three area in Central Japan. Those areas are the followings (Fig. 1): (a) central Kanto plain for the agricultural usages of groundwater, (b) Kujukuri area in Boso Peninsula in southeast Kanto region for groundwater mining for natural gas and iodine, and (c) the Niigata plain in North part of Central Japan for snow melting usage of groundwater.

\section{$3 \quad$ Result and Discussion}

\subsection{Agricultural Usage of Groundwater}

It can be observed that the annual vertical variations clearly depend on the site location. Figure 2 shows the time series of the vertical component of some of the GEONET sites in the Kanto region as well as the location of those sites. In central Kanto plain, we detect vertical movements that may be due to agricultural usage of ground water at Tsukuba and Sanwa GEONET sites. At Tsukuba GEONET site (VLBI colocation site) in the campus of GSI (Geospatial Information Authority of Japan), annual variations are observed likely caused by the groundwater pumping of the rise paddy field around the site, in harmony with VLBI and groundwater level observations (Munekane et al. 2004). Figure 3 shows the annual variation of Tsukuba GEONET site (92110 site) during 1997 and 2009, as well as the VLBI vertical component analyzed by BKG (Federal Agency for Cartography and Geodesy) in Germany (IVS Combination Center 2017), and annual variation of nearby groundwater level in 1997 (Tobita et al. 2004). For those three observations, the phases of annual motion coincide because groundwater pumping is used to irrigate the paddy fields surrounding 
Fig. 1 GEONET sites in Central Japan, and the region of (a) central Kanto plain for the agricultural usages of groundwater, (b) Kujukuri area in Boso Peninsula in southeast Kanto region for groundwater mining for natural gas and iodine, and (c) the Niigata plain in North part of Central Japan for snow melting usage of groundwater
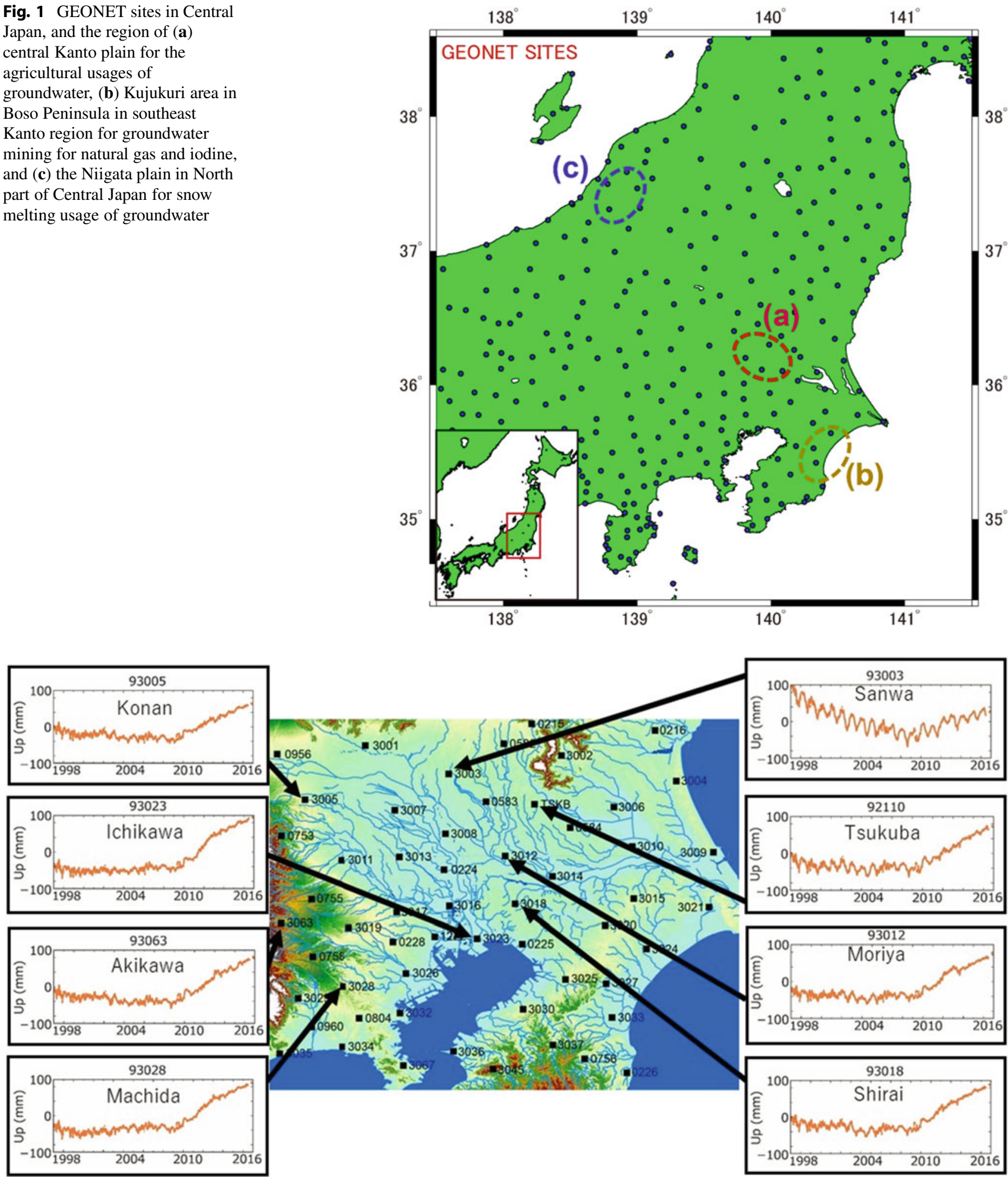

Fig. 2 Location of GEONET sites (central map) and the time series of vertical component of daily coordinate solutions at some of GEONET sites in Kanto area

the GSI campus mainly in spring and summer seasons (Munekane et al. 2010). Comparing the amplitudes of annual variations of GNSS and VLBI measurements, VLBI shows smaller amplitude because the foundation pile of VLBI is driven in the midst of aquifer and deeper than that of GNSS. 

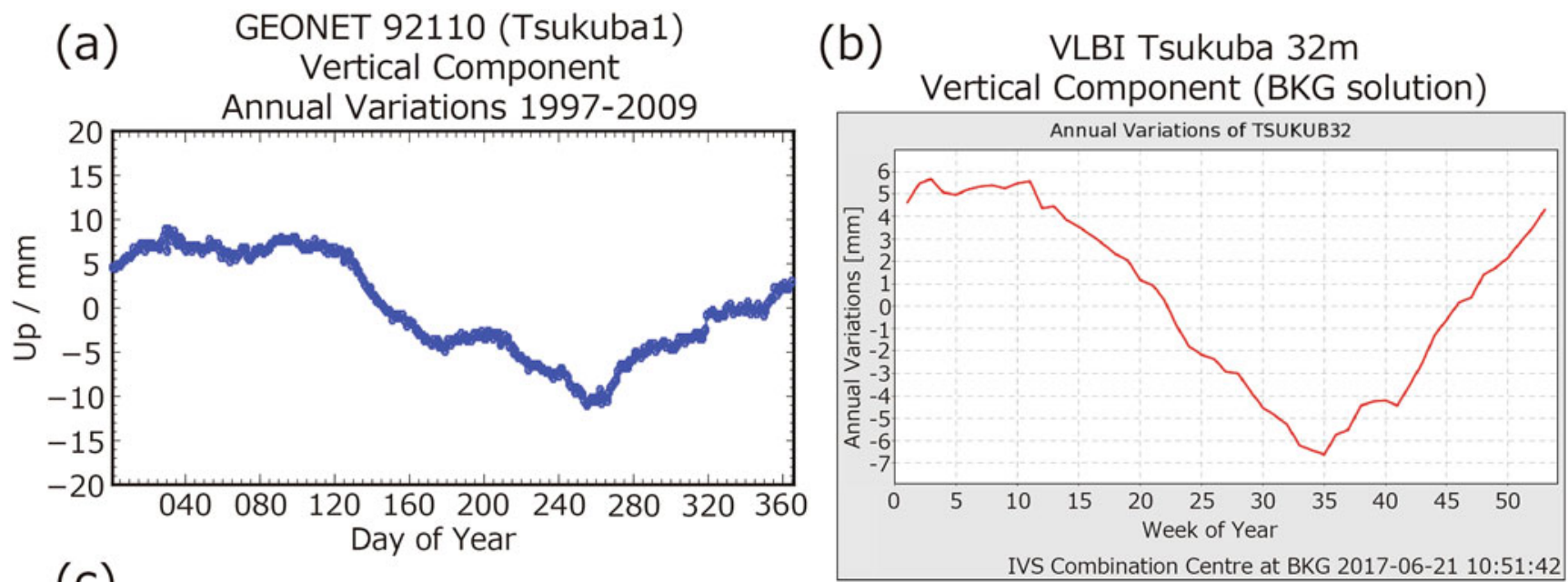

(c)

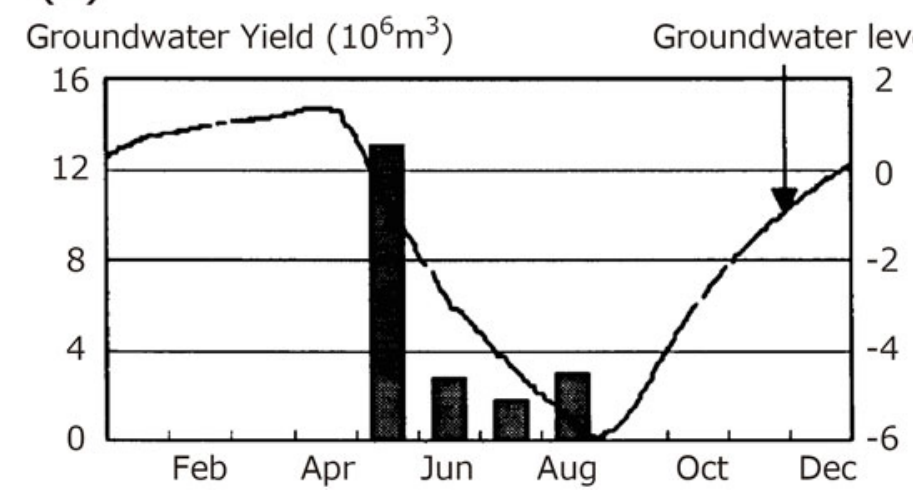

Fig. 3 (a) Annual variation of vertical component at the GEONET site in the campus of GSI during 1997 and 2009. (b) Annual variation of vertical components of the VLBI site in the campus of GSI obtained by BKG (IVS Combination Center 2017). (c) Annual variation of

groundwater level of the W4 well at GSI in 1997 and the groundwater yield per month for irrigation in Tsukuba City in 1996 (Tobita et al. 2004)

prior to the 2011 earthquake is the future research subject. The leveling survey (Fig. 5) shows almost the same amount of secular subsidence at Nogi Uruushima leveling point $6.2 \mathrm{~km}$ northwest of Sanwa site (Tochigi Prefecture 2010), but once-per-year survey does not reveal annual variations. Sanwa and Nogi Uruushima sites located in the middle of the area are well known to undergo subsidence caused by groundwater pumping thought to be used for agricultural groundwater usage (Seki and Koyama 1998; Ministry of the Environment Water and Air Environment Bureau 2020).

At Nogi Uruushima near the leveling point in Fig. 5 there is the Ground Subsidence Observatory that reveals annual variations of groundwater level and compaction by ground subsidence gage. We calculate the long period groundwater level and ground subsidence at gage observations (Tokunaga 2015; Aichi 2008) which reveal annual variations of ground subsidence as well as secular subsidence (Fig. 6). However, a leveling survey realized once per year is totally insufficient to confirm the model as shown in the figure. Contributions of GNSS measurements provide temporal information image of the mechanism of the precursor, thus the movement 


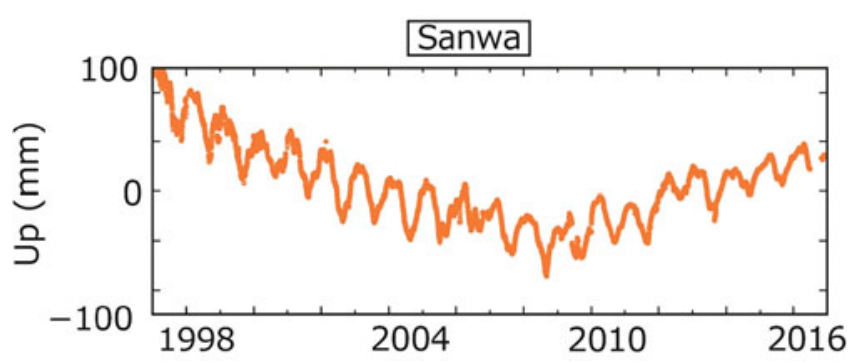

Fig. 4 Time series of vertical component of daily coordinate solution at Sanwa GEONET site during 1997 and 2016

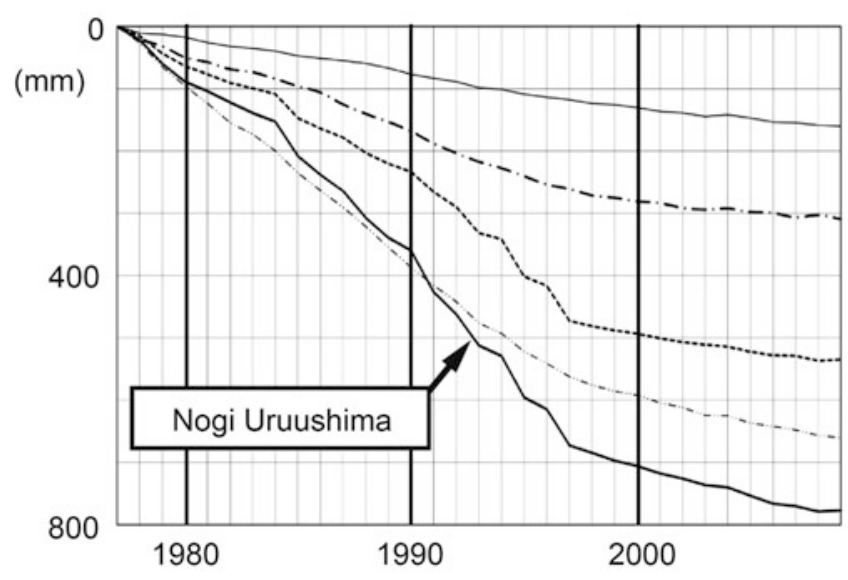

Fig. 5 Time variation of height by leveling survey at Sano Funazukawa, Ashikaga Kenmachi, Oyama Otome, Fujioka Shimomiya, and Nogi Uruushima during 1977 and 2009. Nogi Uruushima indicates the largest subsidence (Tochigi Prefecture 2010)

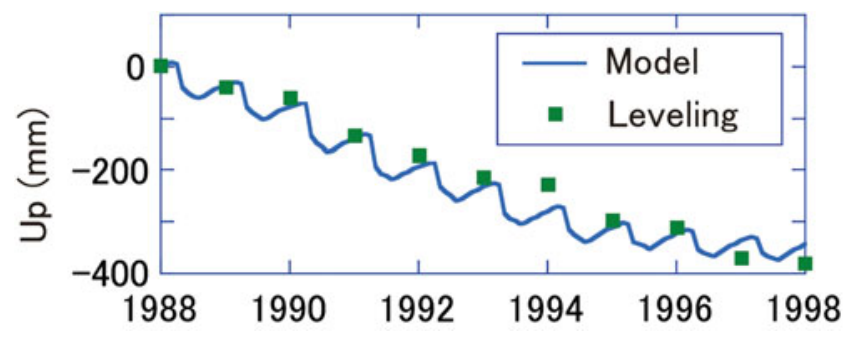

Fig. 6 Time variations of ground subsidence calculated value by the coupled hydrogeological/deformation model applying long period groundwater level and ground subsidence gage observations, and the height by leveling survey both at Nogi Uruushima (Tokunaga 2015)

to validate coupled hydrogeological/deformation simulation of ground subsidence instead of once per year leveling survey.

\subsection{Groundwater Mining for Natural Gas and lodine}

A large amount of subsidence is observed at two GEONET sites in harmony with the level survey (Chiba Prefecture
Environmental Life Department 2016) and the InSAR observations (Fig. 7). The subsidence in the area is widely considered to be caused by the groundwater mining of soluble natural gas and iodine, and the land subsidence is suppressed to some extent by the regulation of the groundwater mining by local government (Nojo et al. 2015; Chiba Prefecture Environmental Life Department 2016; Ministry of the Environment Water and Air Environment Bureau 2020). In Fig. 7 two GEONET sites, Oami Shirasato (93027) and Chosei (93033), secular subsidence is observed from the beginning of the observation in 1997 to 2010 before the occurrence of 2011 East Japan Great Earthquake. After the earthquake, post-seismic uplift is overlaid with the subsidence caused by the groundwater mining. Coseismic step of 2011 earthquake is removed in the figure. In the Kujukuri area, southeast Kanto region, many authors investigated the subsidence applying various methodologies; leveling survey, GNSS, InSAR, GIS, and comparison of those technique (Nojo et al. 2015; Deguchi and Rokugawa 2010; Chen et al. 2015).

\subsection{Groundwater for Snow Melting}

The recent work based on InSAR (Morishita et al. 2020) measurements clarifies that large annual movement in the Niigata area could be caused by the groundwater usage for snow melting. Inland Niigata prefecture is famous for suffering heavy snow in winter season. In the area groundwater is used for snow melting on roads, and on roofs and gardens in private houses, and the groundwater usage for snow melting causes significant subsidence (Kayane 1980; Morishita et al. 2020). At many GEONET sites in Niigata prefecture, annual vertical subsidence is observed where the subsidence is widespread inland the prefecture (right three sites in Fig. 8). The result is confirmed by a levelling survey (Niigata Prefecture Life and Environment Department 2019), although the sites near coastal area where there are less snowfalls do not show significant annual movements (left three sites in Fig. 8). The peaks of the subsidence are in winter season in consistency with the snow-melting usage of groundwater, different from the summer season in the Kanto region where groundwater is pumping and used for agriculture.

For the period after 2011 East Japan Great Earthquake, the post-seismic deformations are widely significant in eastern Japan including the Niigata prefecture. The deformations are described with exponential and/or logarithmic functions with the origin time of earthquake occurrence (Tobita 2016). Niigata prefecture locates near the border of the post-seismic uplift/subsidence of the 2011 earthquake. Thus although the sites in Fig. 8 show slight uplift deformations (Geospatial Information Authority of Japan 2019), the linear trends are 


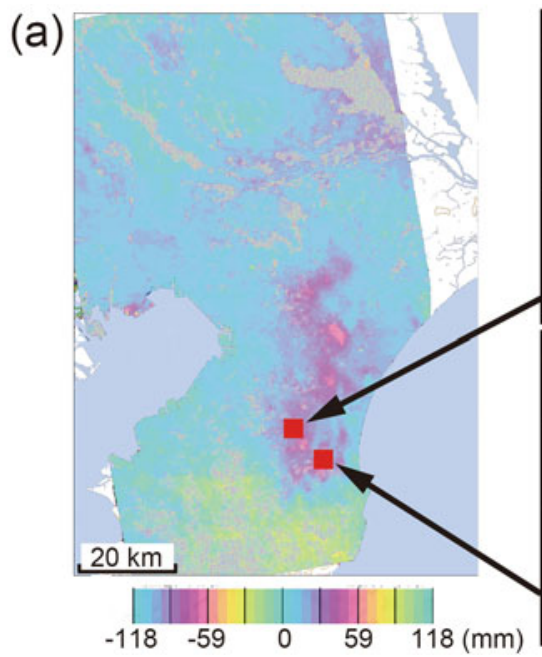

Fig. 7 (a) Subsidence rate at Kujukuri area derived from the InSAR observation (GSI 2020) and the location of Oami Shirasato and Chosei GEONET sites. The map was obtained by ALOS mission and time interval of 2008/02/11 and 2011/02/19. (b) Time series of vertical

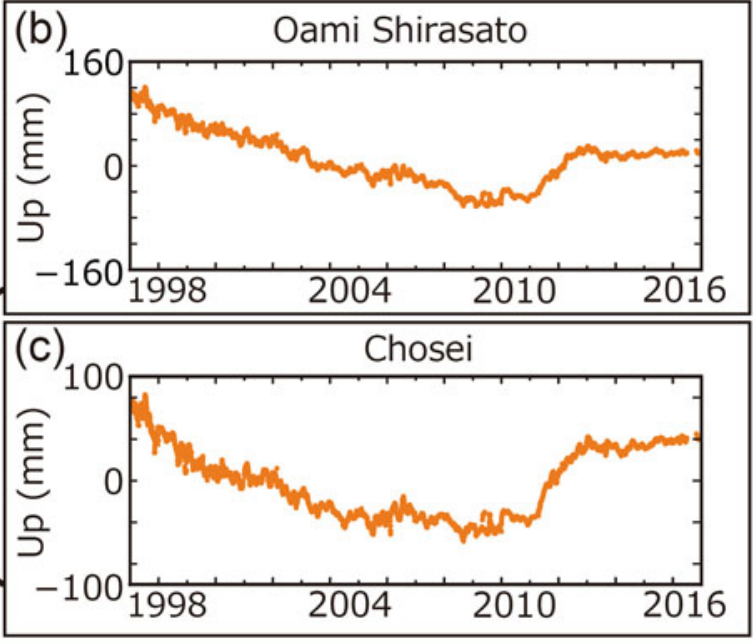

component of daily coordinate solution at Oami Shirasato GEONET site during 1997 and 2016. (c) Time series of vertical component of daily coordinate solution at Chosei GEONET site during 1997 and 2016
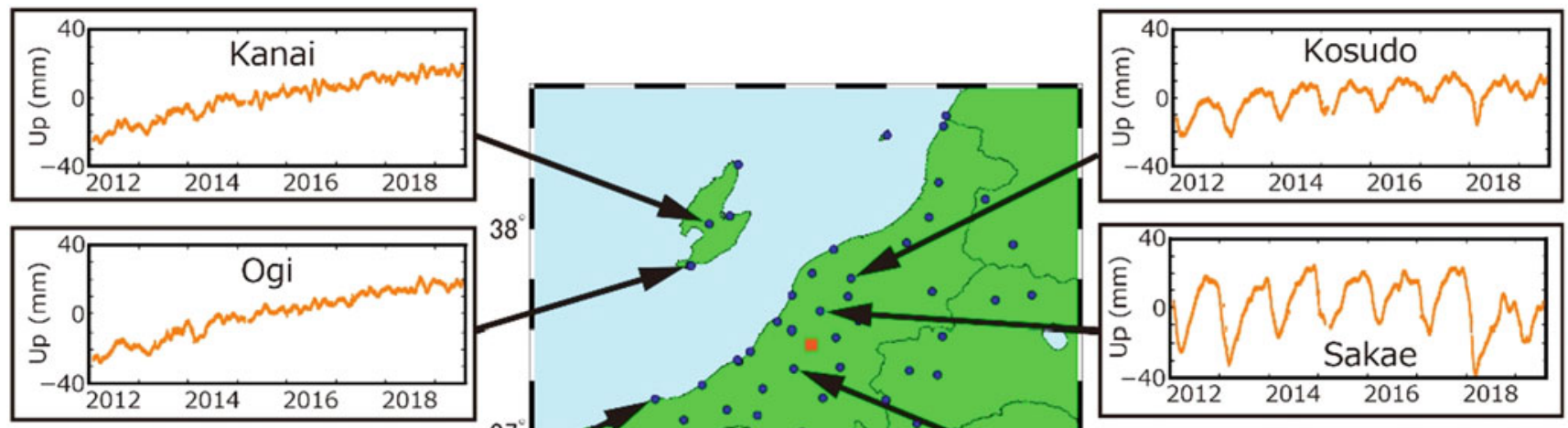

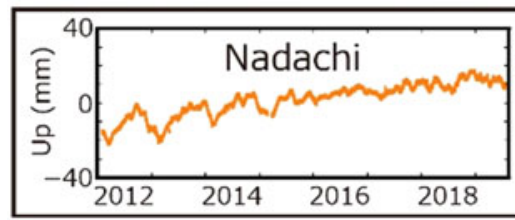

Fig. 8 Location of GEONET sites in Niigata Prefecture (central map) and the time series of vertical component of daily coordinate solutions at GEONET sites, Kanai (960565), Ogi (950235), Nadachi (950243) (from upper to lower in left figures), Kosudo (960571), Sakae (970810),

mostly caused by the post-seismic deformation of the 2011 earthquake and not related to anthropogenic effects.

Niigata Prefecture Life and Environment Department (2019) shows that in the year of heavy snowing groundwater level observations become lower than usual year, and also subsidence gauges show rapid subsidence. Recently 2018, for instance, is well known as the heavy snowing year especially during February 5th and 8th (Niigata Prefecture 2020). In Fig. 8, a significant large amount of subsidence is noticed in 2018 at the Sakae site (970810). If it is caused by groundwater pumping around the site, the deformation that follows could be partially attributed to nonreversible deformations as well as the elastic reversible deformations, but at the Ojiya site (950240) the nonreversible deformations seems to be not significant. Both kind of deformations could depend on the geology of sites. For the case of the Ojiya site, because of rich groundwater the deformations are mostly within the sandy aquifer. But for the case of Sakae site, for years that present larger snowfalls than usual years and significant pumping of groundwater, the deformations may also reach the clay layer which may lead to significant non-reversible subsidence. 
GNSS measurements must also contribute to sustainable groundwater usage for snow melting by better understanding the nature of annual and secular subsidence caused by the snow melting usage of groundwater.

Civil engineering requires monitoring of river and coastline bank heights to prevent flood and high tide damages. Monitoring of annual and secular subsidence using GNSS measurements must provide accurate and temporally dense information of subsidence compared with traditional leveling survey, and will become a standard ground subsidence measurement alternative to leveling survey.

\section{Conclusion}

Conventionally, leveling survey has generally been used for geodetic monitoring of land subsidence. However, because leveling survey are realized only once-per-year in the most frequent cases, data of groundwater level and ground subsidence gage are also used for establishing hydrogeological models coupled with crustal deformations in order to monitor ground subsidence caused by groundwater usage. Continuous GNSS monitoring are more interesting in terms of frequency and immediacy compared with leveling survey. They are also more interesting in terms of cost and they directly measure the ground subsidence compared with ground subsidence gage. Finally, they are more interesting in terms of installation/setup compared with other types of geodetic measurements and measurements that require a dedicated well. This paper demonstrates that mm level accuracy daily monitoring of GNSS measurements is useful for studying ground subsidence, and for establishing coupled hydrogeological/deformation simulation of ground subsidence.

Acknowledgements On the annual and semi-annual tidal components, Dr. Tamura of NAO Mizusawa let us know useful information. The Geospatial Information Authority of Japan provides GEONET RINEX files and PCV models. This research is supported JSPS KAKENHI Grant Number 18K03774 and the research program "Development of Underground Water Utilization System in Case of Disaster" of SIP (Cross-ministerial Strategic Innovation Promotion Program) research fund of Japanese Government. We use GMT program by Wessel and Smith (1998) to draw figures.

\section{References}

Aichi M (2008) Coupled groundwater flow/deformation modelling for predicting land subsidence. In: Takizawa S (ed) Groundwater management in Asian cities: technology and policy for sustainability. Springer-Verlag, Tokyo, pp 105-124. (Chap. 5)

Altamimi Z, Rebischung P, Métivier L, Collilieux X (2016) ITRF2014: a new release of the International Terrestrial Reference Frame modeling nonlinear station motions. J Geophys Res 121:6109-6131. https://doi.org/10.1002/2016JB013098
Boucher C, Altamimi Z, Sillard P (1998) Results and analysis of the ITRF96. International Earth Rotation Service (IERS) Technical Note \#24

Chen HL, Ito Y, Sawamukai M, Su T, Tokunaga T (2015) Has land subsidence changed the flood hazard potential? A case example from the Kujukuri Plain, Chiba Prefecture, Japan. Proc IAHS 372:157161. https://doi.org/10.5194/piahs-372-157-2015

Chiba Prefecture Environmental Life Department (2016) Current status of land subsidence in Chiba prefecture. (in Japanese) https://www. pref.chiba.lg.jp/suiho/jibanchinka/torikumi/documents/h27gaikyou. pdf. Accessed 02 May 2020

Deguchi T, Rokugawa S (2010) Monitoring of land subsidence around Kanto Plains of Japan by DlnSAR and time series analysis. EUSAR 2010. VDE Verlag GmbH. European Conference on Synthetic Aperture Radar (EUSAR), 2010-06-07 - 2010-06-10, Aachen, Deutschland. ISBN 978-3-8007-3272-2

Dong D, Fang P, Bock Y, Cheng MK, Miyazaki S (2002) Anatomy of apparent seasonal variations from GPS-derived site position time series. J Geophys Res 107:2075-2081. https://doi.org/10.1029/ 2001JB000573

EOST Loading Service (2015). http://loading.u-strasbg.fr/displ_maps. php. Assessed 14 May 2021

Geospatial Information Authority of Japan (2019) Eight years after from 2011 Tohoku Earthquake. https://www.gsi.go.jp/kanshi/ h23touhoku_8years.html. Accessed 29 June 2019

Geospatial Information Authority of Japan (2020). https://maps. gsi.go.jp/\#10/35.660644/140.210266/\&base=english\&ls=english \%7Calos_subsidence_kujyukuri_20080211-20110219. Accessed 02 May 2020

Global Geophysical Fluid Center (2020). https://ldas.gsfc.nasa.gov/ gldas. Assessed 14 May 2021

Hatanaka Y, Iizuka T, Sawada M, Yamagiwa A, Kikuta Y, Johnson JM, Rocken C (2003) Improvement of the analysis strategy of GEONET. Bull Geogr Surv Inst 49:11-34. https://www.gsi.go.jp/ common/000001182.pdf. Accessed 06 Sep 2020

Heki K (2001) Seasonal modulation of interseismic strain buildup in Northeastern Japan driven by snow loads. Science 293:89-92. https://doi.org/10.1126/science.1061056

Heki K (2004) Dense GPS array as a new sensor of seasonal changes of surface loads. In: Sparks RSK, Hawkesworth CJ (eds) The state of the planet: frontier and challenges in geophysics, Geophys. Monogr., vol 150. American Geophysical Union, Washington, pp 177-196. https://doi.org/10.1029/150GM15

Herring TA, King RW, Floyd MA, McClusky SC (2018) Documentation for the GAMIT/GLOBK GPS analysis software. Department of Earth, Atmospheric, and Planetary Science, Massachusetts Institute of Technology

IVS Combination Center (2017) Annual variations of TSUKUB32. https://ccivs.bkg.bund.de/index.php?uri=quarterly/annual. Accessed 21 June 2017

Kayane I (1980) Groundwater use for snow melting on the road. GeoJournal 4:173-181. https://doi.org/10.1007/BF00705524

Matsumoto K, Takanezawa T, Ooe M (2000) Ocean tide models developed by assimilating TOPEX/POSEIDON altimeter data into hydrodynamical model: a global model and a regional model around Japan. J Oceanogr 56:567-581. https://doi.org/10.1023/A:1011157212596

Matsumoto K, Sato T, Takanezawa T, Ooe M (2001) GOTIC2: a program for computation of oceanic tidal loading effect. J Geod Soc Jpn 47:243-248. https://doi.org/10.11366/sokuchi1954.47.243

Ministry of the Environment Water and Air Environment Bureau (2020) Overview of subsidence areas nationwide 2018FY. http:// www.env.go.jp/water/jiban/gaikyo/gaikyo30.pdf. Accessed 06 Sep 2020

Miyazaki S, Saito T, Sasaki M, Hatanaka Y, Iimura Y (1997) Expansion of GSI's nationwide GPS array. Bull Geogr Surv Inst 43: 23-34 
Miyazaki S, Hatanaka Y, Sagiya T, Tada T (1998) The nationwide GPS array as an Earth observation system. Bull Geogr Surv Inst 44:11-22

Morishita Y, Lazecky M, Wright TJ, Weiss JR, Elliott JR, Hooper A (2020) LiCSBAS: an open-source InSAR time series analysis package integrated with the LiCSAR automated Sentinel-1 InSAR processor. Remote Sens 12:424-452. https://doi.org/10.3390/ rs 12030424

Munekane H (2010) On improving precision of GPS-derived height time series at GEONET stations. Bull Geospatial Inf Auth Jpn 58:39-46. https://www.gsi.go.jp/common/000058372.pdf. Accessed 06 Sep 2020

Munekane H, Tobita M, Takashima K (2004) Groundwater-induced vertical movements observed in Tsukuba, Japan. Geophys Res Lett 31:L12608. https://doi.org/10.1029/2004GL020158

Munekane H, Kuroishi Y, Hatanaka Y, Takashima K, Ishimoto M (2010) Groundwater-induced vertical movements in Tsukuba revisited: installation of a new GPS station. Earth Planets Space 62:711715. https://doi.org/10.5047/eps.2010.08.001

Nakagawa H, Toyofuku T, Kotani K, Miyahara B, Iwashita C, Kawamoto S, Hatanaka Y, Munekane H, Ishimoto M, Yutsudo T, Ishikura N, Sugawara Y (2009) Development and validation of GEONET new analysis strategy (version 4). Bull Geogr Surv Inst 118:39-46. (in Japanese) https://www.gsi.go.jp/common/ 000054716.pdf. Accessed 06 Sep 2020

Niigata Prefecture (2020). http://micos-sc.jwa.or.jp/niigatayuki/ contents_4.html. Accessed 12 May 2021

Niigata Prefecture Life and Environment Department (2019) Subsidence in Nagaoka area. (in Japanese) http://npdas.pref.niigata.lg.jp/ kankyotaisaku/5c87637485a5e.pdf. Accessed 02 May 2020

Nojo M, Waki F, Akaishi M, Muramoto Y (2015) The investigation of a new monitoring system using leveling and GPS. Proc IAHS 372:539-542. https://doi.org/10.5194/piahs-372-539-2015

Rodell M, Houser PR, Jambor U, Gottschalck J, Mitchell K, Meng C-J, Arsenault K, Cosgrove B, Radakovich J, Bosilovich M, Entin JK, Walker JP, Lohmann D, Toll D (2004) The Global Land Data Assimilation System. Bull Am Meteor Soc 85(3):381-394. https:// doi.org/10.1175/BAMS-85-3-381
Seki Y, Koyama J (1998) New findings on ground subsidence in the central and northern regions of the Kanto Plain (Groundwater level fluctuation-ground fluctuation cycle). Chishitsu News no. 531, 5264. (in Japanese) https://www.gsj.jp/data/chishitsunews/98_11_06. pdf. Accessed 06 Sep 2020

Shimada S (2012) Comparison of the coordinates solutions between the absolute and the relative phase center variation models in the dense regional GPS network in Japan. Geodesy Planet Earth:651656. https://doi.org/10.1007/978-3-642-20338-1_80

Tobita M (2016) Combined logarithmic and exponential function model for fitting postseismic GNSS time series after 2011 Tohoku-Oki earthquake. Earth Planets Space 68:41-52. https://doi.org/10.1186/ s40623-016-0422-4

Tobita M, Munekane H, Kaidzu M, Matsuzaka S, Kuroishi Y, Masaki Y, Kato M (2004) Seasonal variation of groundwater level and ground level around Tsukuba. J Geod Soc Jpn 50:27-37. https://doi.org/10. 11366/sokuchi1954.50.27

Tochigi Prefecture (2010) Report of ground deformation and groundwater level survey in Tochigi prefecture. Utsunomiya Tochigi Japan. (in Japanese) http://www.pref.tochigi.lg.jp/d03/eco/kankyou/hozen/ documents/21jiban.pdf. Accessed 02 May 2020

Tochigi Prefecture (2018) Report of ground deformation and groundwater level survey in Tochigi prefecture. Utsunomiya Tochigi Japan. (in Japanese) http://www.pref.tochigi.lg.jp/d03/eco/kankyou/hozen/ jiban_houkoku_2017.html. Accessed 06 Sep 2020

Tokunaga T (2015) Groundwater management after the cessation of land subsidence: lessons learnt from the Tokyo Metropolitan Area. J Assoc Groundwater Hydrol 57:37-43. (in Japanese). https://doi.org/ 10.5917/jagh.57.37

Tregoning P, Herring TA (2006) Impact of a priori zenith hydrostatic delay errors on GPS estimates of station heights and zenith total delays. Geophys Res Lett 33:L23303. https://doi.org/10.1029/2006/ GL027706

Wessel P, Smith WHF (1998) New, improved version of the generic mapping tools released. EOS Trans AGU 79:579. https://doi.org/10. 1029/98EO00426

Open Access This chapter is licensed under the terms of the Creative Commons Attribution 4.0 International License (http://creativecommons.org/ licenses/by/4.0/), which permits use, sharing, adaptation, distribution and reproduction in any medium or format, as long as you give appropriate credit to the original author(s) and the source, provide a link to the Creative Commons license and indicate if changes were made.

The images or other third party material in this chapter are included in the chapter's Creative Commons license, unless indicated otherwise in a credit line to the material. If material is not included in the chapter's Creative Commons license and your intended use is not permitted by statutory regulation or exceeds the permitted use, you will need to obtain permission directly from the copyright holder.

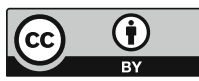

